Reprod. Nutr. Dévelop., 1986, 26 (2 B), 659-667.

\title{
Nutritional advantages of constituents of infant formulae formely called " humanised "
}

\author{
P. R. GUESRY, Marie-Christine SECRETIN, Ph. GOYENS
}

NESTEC Ltd, 1800 Vevey, Suisse.

Terms like " maternized or " humanised " attached to infant formulae are misleading and should not be used anymore. The modifications to cow's milk to adapt it to the nutritional requirements of infants result in a product that is quite far from human milk particularly with respect to the immunological components. The correct term for these products is " adapted formulae ».

Basically there are two kind of adaptations, quantitative and qualitative and almost all categories of nutrients are modified.

\section{Protein adaptation}

a) Quantitative. - The first adaptation is a reduction of about 50 per cent of the total quantity of protein from $35 \mathrm{~g} / \mathrm{l}$ in cow's milk (CM) to $15-17 \mathrm{~g} / \mathrm{l}$ for a modern infant formula (IF). The main reasons for this are the limited digestive and absorptive capacities of young infants for protein. The second is to reduce renal solute load since all the proteins in excess of the needs of the baby for maintenance and growth are catabolised with formation of urea needing water to be eliminated by the kidneys. The immature kidney has only limited capacities of concentration (1). The use of non diluted $\mathrm{CM}$ has been responsible (2) for hyperosmotic dehydration mainly due to the high level of electrolytes in cow's milk but also partly due to the level of protein. The third reason for reducing the protein level is to minimise the risk of acidosis. The newborn's kidney is unable to buffer an excess of acid produced as a result of the metabolism of sulphur containing amino acids. However, acidosis although frequent in low birth weight infants, is very rare in term infants even with protein level as high as $5,7 \mathrm{~g} / \mathrm{kg} / \mathrm{day}(3)$.

A hypothetical reason would be the stimulation of insulin secretion by excess of amino acids.

Some authors (4) ask for an even greater reduction of the protein level to bring it even closer to the level of HM of about $11 \mathrm{~g} / \mathrm{l}$.

This proposal does not take full account of the important physiological variations in humans. The protein level in $\mathrm{HM}$ (fig. 1) varies from above $30 \mathrm{~g} / \mathrm{l}$ at birth to $14 \mathrm{~g} / /$ after 1 week to reach the level of $11 \mathrm{~g} / 1$ only after several weeks (5). 


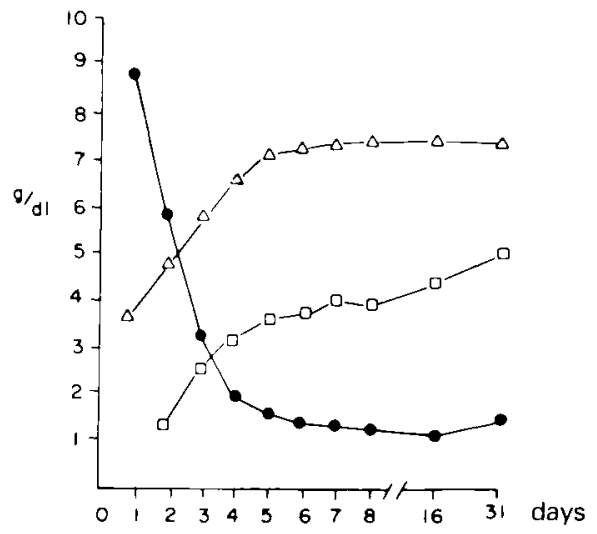

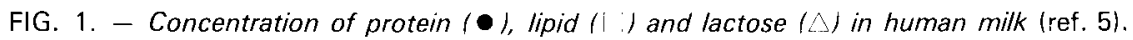

Why should manufacturers select the lowest level of the range corresponding to a period of slower growth ? There may be also possibilities of transamination due to the high level of non protein nitrogen in HM which could increase the level of some aminoacids when needed. Absorption of protein in the infant could vary from one day to the other in relation to many factors such as intestinal transit time or infection, presence of fiber from other food etc. The needs could also vary from day to day. Finally we have to remember that even with the latest technologies and in spite of great progress, the heat treatment necessary for conservation of formulae leads to a certain destruction or blockage of some amino acids like lysine (6) whereas in fresh HM the total quantity of amino acids is available.

These are the reasons why industry should keep a certain security margin and not try to go down to the same level as HM, taking also into account the fact that only large quantities of protein given during long periods to uninephrectomized rats (7) have been proven harmful.

The hypermethioninemia observed in infants (8) happened with enormous quantities of protein : 7-16 g/ kg/day and there were no clinical symptoms. By contrast Zoppi et al. (9) have published deficient immunoglobulin synthesis when the protein diet was insufficient in quantity or in quality.

b) Qualitative. - Due to the specificity of the aminoacids necessary to synthesize the new proteins characteristic of rapid infant growth, it is important that the quantity of individual essential or semiessential amino acids present in formulae should be higher or equal to the quantity present in HM. The level of cystine is for example in $\mathrm{CM}$ at $60 \%$ of the HM level. Change in casein/whey ratio will raise the level of cystine. On the other hand some amino acids like tyrosine or phenylalanine are considered toxic for the developing brain of the new born when the plasma level reaches 100 micromoles/dl for tyrosine or 60 micromoles/dl for phenylalanine. These levels could be reached in low birth weight infants (10) especially for tyrosine (fig. 2) with formulae too rich in protein and when the ratio casein/whey has not been modified. 


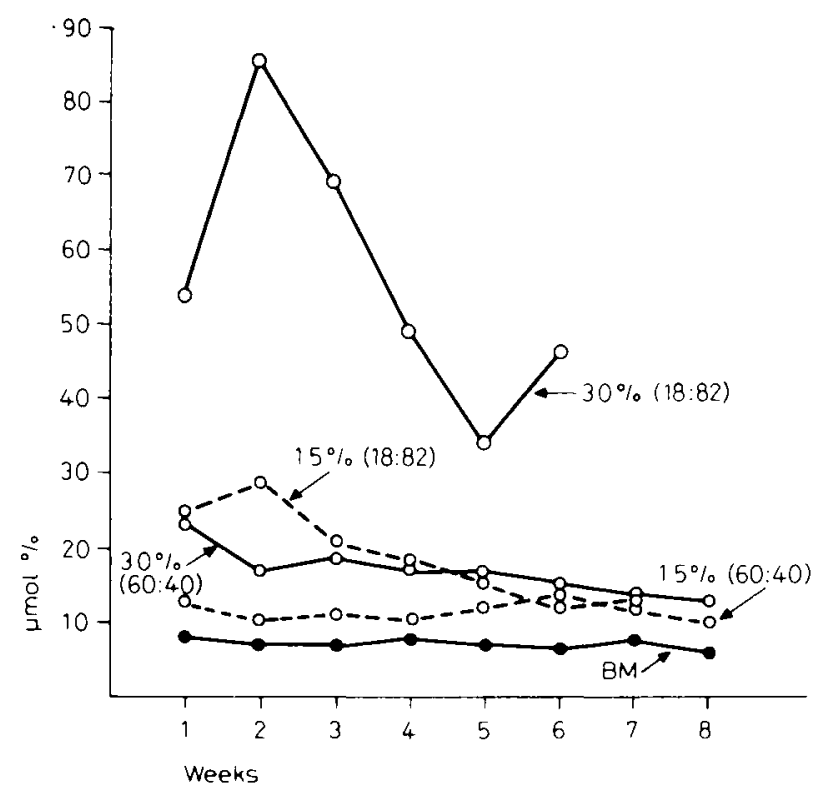

FIG. 2. - Blood tyrosine levels in preterm infants (ref. 10).

By extension and as a legitimate precaution, even for the healthy neonate, changes in the casein/whey ratio could be associated with protein reduction to further reduce the level of these amino acids.

Very recently manufacturers have added to If taurine which could be considered an amino acid even if taurine is not incorporated into protein. Taurine is abundant in human milk and plays a role in synthesis of bile acids. It is also important in some mammals for the normal functioning of the retina. In healthy term infants, and even low birth weight infants (LBW), in spite of numerous studies aimed at proving importance of taurine nothing convincing has been shown (11). By contrast in LBW infant fat absorption seems to be significantly reduced.

\section{Carbohydrate adaptation.}

Human milk contains on average about $74 \mathrm{~g}$ of carbohydrate $(\mathrm{CHO})$ per litre whereas $\mathrm{CM}$ contains only about $48 \mathrm{~g} / \mathrm{I}$ (12). Adaptation consists of raising the level of $\mathrm{CHO}$ up to $\mathrm{HM}$ level. The quality of the $\mathrm{CHO}$ added to IF has become an issue for 3 main reasons : - Sweetness, - Dental caries, - Osmolarity.

In the old days the $\mathrm{CHO}$ usually added was sucrose. In the modern adapted IF the $\mathrm{CHO}$ added is either lactose or dextrin maltose (DM). The advantages of lactose are that it is less sweet than sucrose or fructose and doesn't induce overconsumption of IF which could lead to infantile obesity (13). Lactose is a less potent inducer of dental plaque than is sucrose and a less potent acid producer 
(table 1) (14), although the first tooth usually does not appear much before the cessation of consumption of these starter IF.

TABLE 1

Acid production rate in dental plaque suspension from different carbohydrates expressed as percent of the rate from glucose.

\begin{tabular}{|c|c|}
\hline Substrate & Acid production rate $(\%)$ \\
\hline Glucose & 100 \\
\hline Sucrose $\ldots \ldots \ldots \ldots \ldots \ldots$ & 100 \\
\hline Glucose syrups (DE 40 and 60 ) .... & 100 \\
\hline Fructose $\ldots \ldots \ldots \ldots \ldots \ldots$ & $80-100$ \\
\hline Lactose . . . . . . . . . . . . . & $40-60$ \\
\hline Maltitol-Sorbitol .... & $10-30$ \\
\hline Mannitol-Xylitol & 0 \\
\hline
\end{tabular}

Lactose also enhances net absorption and net retention of calcium as well as absorption of magnesium and manganese (15). It has also been said that lactose (16) probably through lactic acid acidifies the stool of the baby, prevents growth of pathogens or by formation of lactulose (17) working as bifidus factor.

The advantage of DM is based on its low osmolarity in solution which becomes an important issue since necrotizing enterocolitis, mainly in low birth weight infant but sometimes in newborn, has been related to an excessive osmolarity of the IF. The committee on nutrition of the American Academy has issued recommendations (18) related to the osmolarity of infant formulae. Table 2 shows the osmolarity of solutions of lactose or of DM of various degrees of polymerisation. It is clear that at the level usually found in IF replacement of a large quantity of lactose by DM drastically reduces the osmolarity of the solution.

\section{TABLE 2}

Osmolarity of a solution of $50 \mathrm{~g} / /$ of lactose or of DM of decreasing degree of polymerisation.

\begin{tabular}{ccccc}
\hline Concentration $\mathrm{g} / \mathrm{l}$ & \multicolumn{4}{c}{ Osmolarity mOsm// of water } \\
\hline \\
\cline { 2 - 5 } $50 \mathrm{~g} / \mathrm{Lactose}$ & MD 02 & MD 05 & MD 25 \\
\cline { 2 - 5 } & 150 & 33 & 51 & 77 \\
\hline
\end{tabular}

Due to the fact that lactase activity appears quite late in the ontogeny of the gut in contrast with alpha-amylase and maltase and in spite that the level of lactase is generally adequate in newborn to digest about $50 \mathrm{~g}$ of lactose per day, some authors attribute infant colic to the lactose content of HM or IF. Dextrin maltose is thought to be much more easily digested.

\section{Fat adaptation.}

The total concentration of fat in HM (36 to $47 \mathrm{~g} / 1)$ and in $\mathrm{CM}(38 \mathrm{~g} / 1)$ are approximately the same (12). 
During the adaptation of $\mathrm{CM}$, it is important to keep a high level of fat since fat brings $9 \mathrm{kcal}$ per $\mathrm{g}$ when $\mathrm{CHO}$ or protein brings only $4 \mathrm{kcal}$ per $\mathrm{g}$. Moreover fat is not responsible for any osmolarity since it is not soluble in water. The addition of fat should take into account not only the fatty acid pattern, the rate of absorption but also the metabolic result or even the potential toxicity.

Fat absorption is inversely proportional to the length of the chain and directly proportional to the number of unsaturated bonds (fig. 3) (19).

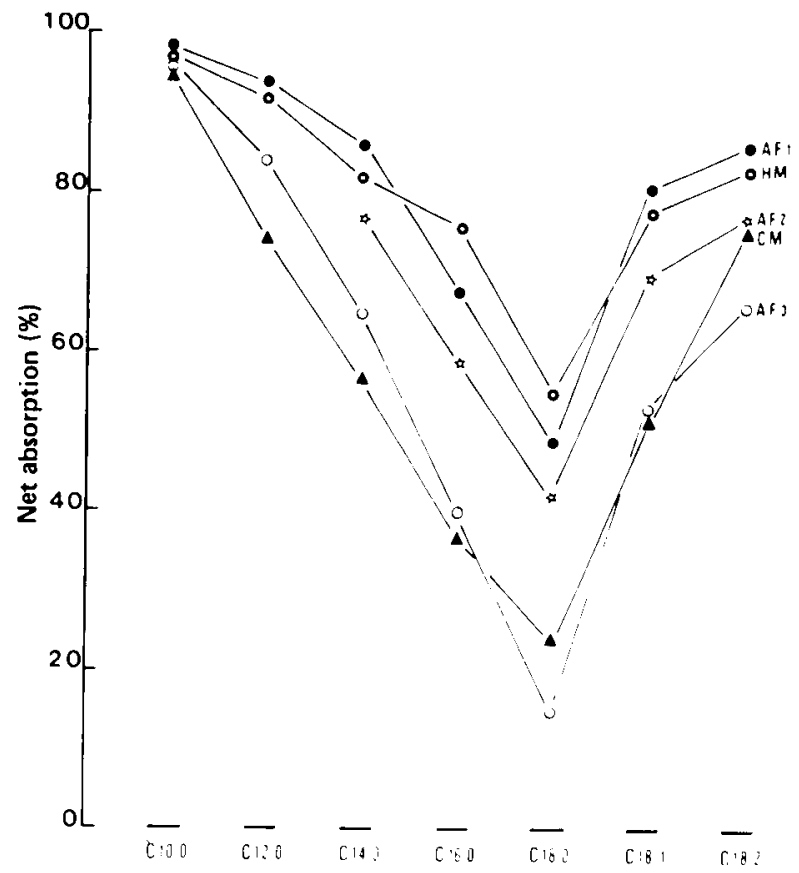

FIG. 3. - Net absorption of various fatty acids in $L B W$ infants fed pasteurized pooled human milk (HM), various adapted formulaes (AF1, AF2, AF3) or a cow's milk formula (CM). (ref. 19).

Despite the large proportions of palmitic acid (C $16: 0$ ) $\mathrm{HM}$ fat is well absorbed (20) probably due to the fact that most of its palmitic acid is esterified in the beta position (21). Among fats available for infant feeding lard is the one with the highest percentage of palmitic acid in the beta position $(83 \%)$ followed by $\mathrm{CM}$ fat $(43 \%)$ whereas vegetable fats contain no more than $10 \%$ of palmitic acid in the beta position. This makes $\mathrm{CM}$ fat fairly well absorbed (22). Optimal fat absorption is not only important for energy balance but also for calcium absorption since there is direct relationship between fat and calcium absorption (23).

Regarding the long term potential consequences of early feeding it is clear that the level of plasma cholesterol of infants receiving formulae with vegetable fat (24) is much lower than the level of cholesterol of breast fed infants.

This raises the question of late atherosclerosis when the level of plasma cholesterol remains low during the period of enzyme induction and when the ratio HDL/VLDL (25) is different from the one with HM.

Reproduction, Nutrition, Développement, $n^{\circ} 2$ B-86. -10 
Due to the potential risk of atherosclerosis (26) the EEC scientific committee for food (27) have fixed a maximum level of $15 \%$ of the fat content for lauric and myristic acid in IF.

The essentiality of linoleic acid has been recognised for a long time (28). The level in IF should be in the same range as BM between 6 and $16 \%$ of the total fat (29) varying according to the mother's diet. Linoleic acid is important for maintenance of functional integrity of cell membrane and synthesis of prostaglandins (30). The importance of linolenic acid, arachidonic and C22 : 6 has been recognized lately (31).

Finally one should not forget potential toxicity of some fatty acids contained for example in cotton seed oil (32) like malvalic acid and sternilic acid responsible for deleterious mitogenic effects.

\section{Mineral adaptation.}

As previously mentioned the high level of electrolytes in CM opposed to the low level in HM has been responsible for hypernatremic dehydration when dilution instructions were not correctly followed. One important adaptation is to reduce the level of sodium from about $500 \mathrm{mg} / \mathrm{l}$ in $\mathrm{CM}$ to 150 to $200 \mathrm{mg} / \mathrm{l}$ level found in $\mathrm{HM}$ (33) (fig. 4).

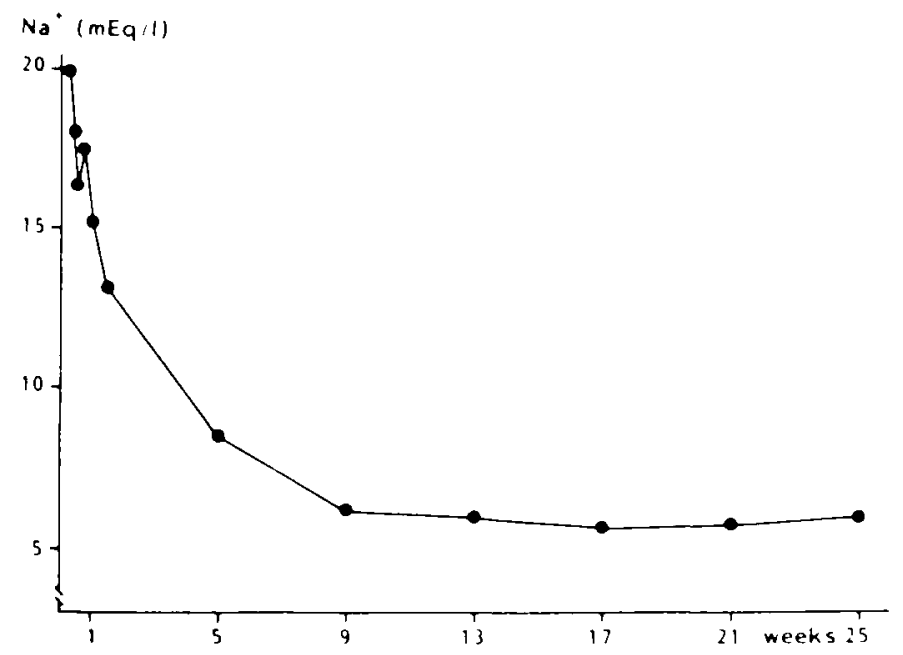

FIG. 4. - Sodium concentration of human milk in the first six months postpartum (ref. 33).

Potassium and chloride should be reduced in about the same proportions. The potassium/sodium ratio should be above 2 and to avoid too low a level of chloride which otherwise induces dangerous alkalosis and hypercalciuria (34). Recently (35) the question whether low sodium infant formulae could prevent hypertension in adults has been raised. The long term consequences of early dietary manipulation is still uncertain (36). Other factors like calcium content of diet play an important role in the subsequent development of adult hypertension (37). 
Calcium and phosphorus adaptation are very important for bone growth of the infant. Calcium level in $\mathrm{CM}$ is about 3 times higher than in $\mathrm{HM}$ while phosphorus level is about 6 times higher resulting in a $\mathrm{Ca} / \mathrm{P}$ ratio of about 1,3 in $\mathrm{CM}$ versus 2 in $\mathrm{HM}$. Since we know that $\mathrm{Ca} / \mathrm{P}$ ratio is an important parameter for calcium absorption and retention, manufacturers try to increase this ratio closer to HM ratio.

However we also know that the absorption of calcium is inversely related to the total calcium content of the formulae. In other words increasing the calcium content of a formulae reduces the percentage of calcium absorbed and increases the quantity of calcium in the stool. This calcium will combine with fatty acids to give insoluble salts preventing absorption of fat (38). A good way of increasing $\mathrm{Ca} / \mathrm{P}$ ratio is to reduce the phosphorus content of $\mathrm{CM}$ by two third and calcium by half. Such adaptation allows a calcium absorption and retention of $117 \mathrm{mg} / \mathrm{kg} /$ day comparable to $\mathrm{HM}(114 \mathrm{mg} / \mathrm{kg} /$ day $)$ even in premature infants (39).

\section{Trace Minerals.}

The iron content of $\mathrm{CM}$ is not very different from $\mathrm{HM} 0.5 \mathrm{mg} / \mathrm{l}$ versus $0.76 \mathrm{mg} / \mathrm{l}$. However the absorption is very different (40) : about $50 \%$ in $\mathrm{HM}$ and about $10 \%$ in CM. In IF the presence of vitamin C increases iron absorption to about $20 \%$.

This quantity is certainly sufficient for healthy newborns during the first 4 months of life. It becomes insufficient both for breast and artificially fed infants after 4 months. To avoid anemia supplementation of 8 to $12 \mathrm{mg} / \mathrm{l}$ should then be introduced. Copper and zinc have about the same concentration in CM and HM. The mean value of iodine is a bit lower in CM than in HM, but there is a large variation, according to the proximity of the sea. The level is usually sufficient for healthy newborn so addition is generally not necessary.

\section{Vitamins.}

Most vitamins are present in $\mathrm{CM}$ at a lower level than in $\mathrm{HM}$ so a certain adaptation is necessary. This is particularly true for Vit $D, 20$ times less abundant in CM, Vit E 10 times less and for which a further addition is needed in relation to the level of linoleic acid. Vit $C$ should be added because it is sensitive to heat treatment. Moreover a high level of $\mathrm{Vit} C$ is necessary in infant formulae to improve iron absorption (40).

All these nutritional adaptations now give us a very good substitute for HM when breast feeding is not possible for medical, social or economic reasons. However there is still more work to do especially in the field of immunology, to remove the risk of sensitization to foreign protein by use of hydrolysed protein and to provide some non specific protection against enteral infection by addition of substances like lactoferrin, lactoperoxidase, lyzozyme... Even then, it would be difficult to speak of "humanized " formulae since the protection offered by 
mother's milk against infection is adapted to the risk through specific immunoglobulins $A$ and through leucocytes activity.

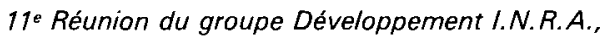
Montpellier, 22-24 mai 1985.

\section{Références}

1. SVENNINGSEN N. W., LINDQUIST B., MEUWISSE G., 1971. Nutrition and homeostasis with special reference to kidney function. Proc. XIII int. Congr. Pediat., II, 509-515.

2. CHAMBeRS T. L., STEEL A. E., 1975 . Concentrated milk feeds and their relation to hypernatraemic dehydration in infants. Arch. Dis. Child, 50, 610-615.

3. SVENNINGSEN N. W., LINDQUIST B., 1973. Incidence of metabolic acidosis in term, preterm and small for gestational age infants in relation to dieraty protein intake. Acta paediatr. scand., 62, 1-10.

4. MORO G., MINOLI I., RAIIHA N., 1984. Milk protein quantity in the term infant: Metabolic responses and effects on growth. Pediatr. Res., 18, 1051.

5. HUANG L., MAO X. L., SHI Z. Z., CHENG H. D., SU T. F., 1984. A longitudinal study of the nutritional and immunological composition of r'sman milk. Nutr. Res., 4, 977-980.

6. FINOT P. A., 1983. Chemical modifications of the milk proteins during processing and storage. Nutritional metabolic and physiological consequences, 357-368. In KAUFMANN W., Role of milk proteins in human nutrition, Th. Mann Verlag, Gelsenkirchen Buer, F.R.G.

7. LALICH S. C., BURKHOLDER P. M., PAIK W. C. M., 1975. Protein overload nephropathy in rats with unilateral nephrectomy. Arch. Path., 99, 72-79.

8. LEVY H. L., SHIH V. E., MADIGAN P. M., 1969. Hypermethioninemia with other hyperaminoacidemias. Amer. J. Dis. Child., 117, 96-103.

9. ZOPPI G., ZAMBINO G., SIVIERO M., BELLINI P., 1978. Globulin level and dietary protein intake during the first year of life. Pediatrics, 62, 1010-1018.

10. RASSIN D. K., GAULL G. E., RÄIHÄ N. C. R., HEINONEN K., 1977. Milk protein quantity and quality in low birthweight infants. IV. Effects on tyrosine and phenylalanine in plasma and urine. J. Pediatr., 90, 356-360.

11. OKAMOTO E., RASSIN D. K., ZUCKER C. L., SALEN G. S., HEIRD W. C., 1984. Role of taurine in feeding the low birthweight infant. J. Pediatr., 104, 936-940.

12. Artificial feeds for the young infant. Rep. Health and social subject, $n^{\circ} 18$. London: Her Majesty's Stationary Office, Department of Health and Social Security. 1980.

13. FOMON S. J., ZIEGLER E. E., NELSON S. E., EDWARDS B. B., 1983. Sweetness of diet and food consumption by infants. Proc. Soc. exp. Biol. Med., 173, 190-193.

14. BIRKHED D., EDWARDSSON S., 1979. Acid production from sucrose substitutes in human dental plaque. 211-217. In GUGGENHEIM B., Health and sugar substitutes. Proc. of the ERGOB Conf. on sugar substitutes, Geneva 1978, Karger, Basel.

15. ZIEGLER E. F., FOMON S. J., 1983. Lactose enhances mineral absorption in infancy. J. Pediatr. Gastroenterol. Nutr., 2, 288-294.

16. WILLIS A. T., BULLEN C. L., WILLIAMS K., FAGG C. G., BOURNE A., VIGNON M., 1973. Breast milk substitute: A bacteriological study. Brit. Med. J., 4, 67-72.

17. KLEINSCHMIDT H., 1949. Versuche zur Anpassung der künstlichen an die natürliche Nahrung des Saüglings. Oesterr. Z. Kinderheilk., 3, 55-66.

18. American Academy of Pediatrics, Committee on Nutrition, 1976. Commentary on breast feeding and infant formulas, including proposed standards for formulas. Pediatrics, 57, 278285.

19. SENTERRE J., RIGO J., 1985. Nutritional requirements of low birthweight infants, 45-62. in GRACEY M., FALKNER F. F., Nestlé Nutrition Workshop Series. Vol. 7, Nutritional needs and assessment of normal growth. New York Raven Press, Vevey: Nestlé Nutrition.

20. HAMOSH M., 1981. Breast milk fat origin and digestion, 62-67. In FREIER S., EIDELMAN A. I., Human milk, its biological and social value, Excerpta med., Amsterdam. 
21. BOEKENOOGEN H. A., 1964-1968. Analysis and characterization of oils, fats and fat products. Intersc. Publ., London.

22. ROYER P., 1973. Bases métaboliques de l'utilisation des laits dits " humanisés ». Pediatr. Fortbild., 37, 15-25.

23. HANNA F. M., NAVARRETE D. A., ANN HSU F., 1970. Calcium fatty acid absorption in term infants fed human milk and prepared formulas simulating human milk. Pediatrics, 45. 216-224.

24. DARMADY J. M., FOSBROOKE A. S., LLOYD J. K., 1972. Prospective study of serum cholesterol levels during first year of life. Brit. Med. J., 2, 685-688.

25. VAN BIERVLIET J. P., VINAIRMONT N., CASTER H., VERCAEMST R., ROSSENEN M., 1981. Plasma apoprotein and lipid patterns in newborns : influence of nutritional factors. Acta paediatr. scand., 70, 851-856.

26. ESPGAN, Committee on nutrition, 1977. Guidelines on infant nutrition. I. Recommendations for the composition of an adapted formula. Acta paediatr. scand. (Suppl.), 262, 1-20.

27. EEC, Scientific Committee for Food, 1985. Offic. J. Eur. Communit., 30.1.85, No C28/3+ C28/15.

28. HANSEN A. E., 1958. Essential fatty acid in infant nutrition. Clinical manifestations of linoleic acid deficiency. J. Nutr., 66, 565-576.

29. American Academy of Pediatrics, Committee on Nutrition, 1960. Composition of milk. Pediatrics, 26, 1039-1049.

30. FRIEDMAN Z., 1982. Effects of dietary variation in linoleic acid content of prostaglandin synthesis in infants, 59-66. In HOLMAN R. T., Essential fatty acids and prostaglandins. Pergamon Press, Oxford.

31. BOURRE J. M., Developmental synthesis of myelin. Specific role of nutrition. In CHANGEUX J. P., EVRARD P., LYON G., MINKOWSKI A., Neurobiological development, Nestlé Nutrition Workshop Ser., Vol. 12, Raven Press, New York, Vevey, Nestlé Nutrition (in press).

32. HENDRICKS J. D., 1980. Hepatocarcinogenicity of glandiess cotton seeds and cotton seed oil to rainbow trout. Science, 208, 309-311.

33. HAZENBROECK A., HOFMAN A., 1983. Sodium content of breast milk in the forst six months after delivery. Acta pediatr. scand., 72, 459-460.

34. RODRIGUEZ-SORIANO J., VALLO A., CASTILLO G., OLIVEROS R., CEA J. M., BALZATEGUI M. J., 1983. Biochemical features of dietary chloride defieciency syndrome. A comparative study of 30 cases. J. Pediatr., 103, 209-214.

35. HOFMAN A., HAZENBROECK A., VALKENBURG H. A., 1983. A randomized trial of sodium intake and blood pressure in newborn infants. J. amer. med. Ass., 250, 370-373.

36. INGELFINGER J. R., 1983. Sodium and blood pressure in infancy. J. amer. med. Ass., 250, 389390.

37. PARROTT-GARCIA M., MAC CARRON D. A., 1984. Calcium and hypertention. Nutr. Rev., 42, 205-213.

38. ChENG A. L., MOREhouse M. G., DEVEL H. S., 1949. The effect of dietary calcium and magnesium on the digestibility of fatty acids, simple triglycerides and some natural and hydrogenate fats. J. Nutr., 37, 237-250.

39. SENTERRE J., LAMBRECHTS A., 1971. Nitrogen, fat and mineral balances in premature infants fed maternal or humanized milk. Proc. 13 th int. Congr. Pediatr. Vienna 1971. Wiener Medizinische Akademie, II/2, 497-502.

40. COOK J. D., BOTHWELL T. H., 1984. Availability of iron from infant foods in iron nutrition, 119-145. In STEKEL A., Infancy and childhood. Nestlé Nutrition Workshop Ser., Vol. 4, Raven Press, New York, Vevey, Nestlé Nutrition. 